\title{
ARTIKEL
}

\section{PERILAKU MASYARAKAT DALAM MENGGUNAKAN MEDIA DIGITAL DI MASA PANDEMI}

\author{
Oleh : Nani Sintiawati \\ Program Studi Pendidikan Luar Sekolah, Fakultas Keguruan dan IImu Pendidikan, \\ Universitas Islam Nusantara, Kota Bandung \\ nanisintiawati@uninus.ac.id
}

\begin{abstract}
Abstrak: Indonesia termasuk salah satu negara yang terkena dampak wabah Covid-19. Kebijakan pemerintah mengenai Pembatasan Sosial Berskala Besar (PSBB) memberikan dampak terhadap berbagai sektor di Indonesia, baik itu sektor ekonomi, hiburan, keagamaan dan pendidikan. Perlunya pemahaman pemanfaatan media digital di masyarakat sangat menentukan pola pikir masyarakat dalam menghadapi pandemi ini. Kegiatan pendidikan yang dihentikan selama masa pandemi, diubah dalam bentuk pembelajaran daring dengan memanfaatkan media digital. Kemudahan mengakses segala informasi melalui beberapa aplikasi dalam gadget di kehidupan masyarakat, namun tidak semua masyarakat memanfaatkan peluang tersebut secara posisitif. Tujuan penelitian ini untuk mengetahui perilaku masyarakat dalam menggunakan media digital di masa pandemik Covid-19. Metode penelitian yang dipakai adalah metode kajian literatur berdasarkan pada eksplorasi literatur dari hasil kajian-kajian terdahulu. Literatur-literatur tersebut berupa buku, hasil survey, media online, dan artikel penelitian nasional. Hasil penelitian mengungkapkan bahwa terjadi perubahan besar terhadap perilaku masyarakat dalam beberapa aspek. Perubahan itu berasal dari inisiatif sendiri maupun himbauan atau perintah dari otoritas yang berwenang. Selain itu, masa pandemi mempengaruhi kesehatan mental dan psikologis masyarakat. Media selalu menjadi lembaga sosial, di masa pandemi ini pembelajaran dapat terlaksana dengan menggunakan berbagai platform, baik berupa learning management system maupun bentuk video conference sehingga orang tua dan pengajar dituntut memiliki kemampuan literasi digital. Kesimpulan penelitian ialah pemanfaatan media digital sangat berpengaruh terhadap perilaku masyarakat, selain itu kemampuan memanfaatkan media digital diperlukan masyarakat sebagai upaya literasi digital di masa pandemi Covid-19.
\end{abstract}

Kata-kata kunci: perilaku masyarakat, media digital, pandemi Covid-19

\section{COMMUNITY BEHAVIOUR IN USING DIGITAL MEDIA IN THE PANDEMIC TIME}

Abstract: Indonesia is one of the countries affected by the Covid-19 outbreak. The government's policy regarding Large-Scale Social Restrictions (PSBB) has an impact on various sectors in Indonesia, be it the economic, entertainment, religious and educational sectors. The need to understand the use of digital media in society greatly determines the mindset of society in dealing with this pandemic. Educational activities that were stopped during the pandemic were transformed into online learning using digital media. Ease of accessing all information can be obtained through several applications in gadgets in people's lives, but not all people take advantage of these 
opportunities positively. The purpose of this study was to determine people's behavior in using digital media during the Covid-19 pandemic. The research method used is the literature review method based on literature exploration from the results of previous studies. These literatures are in the form of books, survey results, online media, and national research articles. The research results reveal that there have been major changes in people's behavior in several aspects. The change comes from one's own initiative as well as an appeal or order from the competent authority. In addition, the pandemic affects the mental and psychological health of the community. Media has always been a social institution, during this pandemic, learning can be carried out using various platforms, both in the form of a learning management system and in the form of video conferencing so that parents and teachers are required to have digital literacy skills. The conclusion of the study is that the use of digital media greatly affects people's behavior, besides that the ability to use digital media is needed by the community as a digital literacy effort during the Covid-19 pandemic.

Key words: community behavior, digital media, Covid-19 pandemic

\section{PENDAHULUAN}

Saat ini dunia sedang dilanda wabah atau penyakit serius yang dapat merenggut setiap nyawa manusia. Covid-19 jenis coronavirus yang baru ditemukan tahun 2019 pada bulan Desember di Kota Wuhan Negara China. Virus ini menyerang setiap individu mulai dari bayi, anak-anak, hingga orang dewasa. Individu yang telah tertular penyakit ini akan memiliki gejala ringan seperti gangguan pada sistem pernapasan, infeksi paru-paru yang berat hingga berujung pada kematian.

Indonesia termasuk salah satu negara yang terkena dampak wabah mengerikan ini. Merujuk pada Undang-undang Bencana Nomor 24/2007 menyatakan 3 jenis bencana: bencana alam, nonalam, dan sosial. Pemerintah resmi mengumumkan bahwa Negara Indonesia sedang mengalami bencana nasional yaitu merebaknya wabah Covid-19. Merujuk pada pemberitahuan bahwa Indonesia sedang mengalami bencana nasional, pemerintah mengeluarkan beberapa kebijakan, salah satunya ialah diberlakukan Pembatasan Sosial Bersekala Besar (PSBB) sebagai upaya menghentikan penularan Covid-19.
Kebijakan tersebut tertuang pada Peraturan Pemerintah Nomor 21 Tahun 2020 yang Mengatur pelaksanaan Pembatasan Sosial Berskala Besar (PSBB), yang ditetapkan oleh Menteri Kesehatan dan dapat dilakukan oleh Pemerintah Daerah berdasarkan persetujuan Menteri Kesehatan. Selanjutnya, Peraturan Menteri Kesehatan Nomor 9 Tahun 2020 Mengatur tentang pedoman mekanisme penetapan, pelaksanaan, pencatatan dan pelaporan, serta pembinaan dan pengawasan Pembatasan Sosial Berskala Besar.

Kebijakan pemerintah mengenai PSBB memberikan dampak terhadap berbagai sektor di Indonesia, baik itu sektor ekonomi, hiburan, keagamaan dan pendidikan. Sesuai dengan Surat Edaran Menpan RB Nomor 19 Tahun 2020 yang mengatur mekanisme pelaksanaan individu dalam bekerja, yaitu bekerja dari rumah (work from home) beserta pengaturan, pelaporan, rapat melalui sarana teleconference, mekanisme evaluasi, perjalanan dinas, serta penerapan standar kebersihan. Selain itu, aturan lainnya adalah Surat Edaran Mendikbud Nomor 3 Tahun 2020 tentang imbauan kepada para Kadisdik Provinsi, Kabupaten/Kota, Kepala Lembaga Layanan Pendidikan Tinggi, Pimpinan 
Perguruan Tinggi, serta Kepala Sekolah agar mempedomani Pencegahan Covid-19 di satuan pendidikan berdasarkan tingkat risiko penyebaran.

Kebijakan mengenai perubahan pelaksanaan pembelajaran selama masa pandemi juga dikeluarkan Kementerian Pendidikan dan Kebudayaan (Kemendikbud), melalui Surat Edaran Nomor 15 Tahun 2020 tentang Pedoman Penyelenggaraan Belajar Dari Rumah dalam Masa Darurat Penyebaran Covid-19. Staf Ahli Menteri Pendidikan dan Kebudayaan Bidang Regulasi, Girsang menyampaikan Surat Edaran Nomor 15 ini untuk memperkuat Surat Edaran Mendikbud Nomor 4 Tahun 2020 tentang Pelaksanaan Pendidikan dalam Masa Darurat Coronavirus Disease (Covid-19). Kegiatan di luar rumah benarbenar dihentikan sampai pandemi Covid-19 betulbetul hilang dari Indonesia.

Selanjutnya para orang tua pun merasa resah dan gelisah melihat anak-anaknya tidak belajar ditengah situasi pandemi Covid-19 ini. Kegiatan pendidikan tentunya tidak dapat dihentikan selama masa pandemi ini, namun bentuk prosesnya yang akan berbeda dengan proses pembelajaran sebelum dimulainya pandemik Covid-19. Seperti yang diungkapkan Dewey (1958) dalam (Sagala, Syaiful: 2013) berpendapat bahwa "Pendidikan adalah proses yang tanpa akhir, dan pendidikan merupakan proses pembentukan kemampuan dasar yang fundamental baik menyangkut daya pikir daya intelektual maupun emosional perasaan yang diarahkan kepada tabiat manusia dan kepada sesamanya. Oleh karena itu, proses belajar menjadi kunci untuk keberhasilan pendidikan agar proses belajar menjadi berkualitas membutuhkan tata layanan yang berkualitas. Keluarga merupakan wadah utama kunci keberhasilan dalam mendidik anak. Orang tua harus menumbuhkan dan meningkatkan minat baca anak dalam situasi pandemi seperti ini supaya anak tetap memperoleh hak mendapatkan pendidikan meskipun dalam keadaan pandemi Covid-19.
Kemajuan teknologi tidak dapat dipungkiri di masa sekarang ini, kemudahan mengakses segala informasi dapat ditemukan melalui beberapa aplikasi dalam gadget. Hal tersebut memberikan peluang yang cukup bagus bagi masyarakat di tengah pandemi Covid-19. Berlakunya kebijakan PSBB mengakibatkan terbatasnya pergerakan masyarakat dalam mengakses informasi, baik itu informasi untuk memenuhi kebutuhan belajar di sekolah maupun informasi bagi masyarakat untuk memenuhi kebutuhan hidupnya. Literasi digital memberikan ruang baru yang dapat memudahkan masyarakat dalam megakses informasi di tengah pandemi Covid-19.

Secara terminologi, literasi baca adalah kegiatan yang melibatkan keterampilan kognisi dan linguistik untuk tujuan tertentu. Ketika berhadapan dengan teks, seseorang akan menjalani rangkaian proses membaca dari memahami, menggunakan, mengevaluasi, hingga merefleksikan teks. Menurut Gilster dalam bukunya yang berjudul Digital Literacy (1997) literasi digital diartikan sebagai kemampuan untuk memahami dan menggunakan informasi dalam berbagai bentuk dari berbagai sumber yang sangat luas yang diakses melalui piranti komputer.

Literasi digital menjadi salah satu pilar penting dalam enam literasi dasar bagi masyarakat dunia, terutama dengan munculnya internet dan penggunaan media sosial. Keberadaan literasi digital ini bukanlah untuk menggantikan literasi konvensional yang selama ini telah akrab dikalangan masyarakat, tetapi lebih kepada melengkapi kompetensi masyarakat dalam bentuk keaksaraan yang lebih fungsional dan sesuai dengan perkembangan zaman (Imran, 2010).

Penelitian Sutrisna (2020) mengungkapkan bahwa Gerakan literasi digital yang dapat dilakukan dalam masa pandemi Covid-19 adalah gerakan literasi keluarga dan gerakan literasi masyarakat. Selain itu, Bungai, dkk (2020) mengungkapkan bahwa literasi digital dapat meningkatkan 
kemampuan dan keterampilan masyarakat sebagai upaya pemberdayaan masyarakat. Kemudian Nurohmah, dkk (2020) mengatakan terdapat beberapa hal yang perlu diambil dan disesuaikan dari kebijakan pemerintah di saat pandemi Covid-19, yaitu bagaimana peran orang tua dapat menerapkan pembelajaran jarak jauh melalui media digital dan bekerja serta belajar dari rumah. Untuk dapat mempergunakan akses internet secara optimal, seorang anak perlu pengawasan dan arahan dari orang tua. Hal tersebut sangat positif dalam rangka mempersiapkan generasi abad 21 yang memiliki kompetensi digital.

Berdasarkan latar belakang di atas dan ditunjang dengan beberapa penelitian terdahulu, maka peneliti tertarik untuk melakukan studi literatur mengenai:

1. Bagaimana perilaku masyarakat di masa pandemi Covid-19?

2. Bagaimana fungsi media digital dalam kegiatan pembelajaran "Belajar dari Rumah" di masa pandemi Covid-19?

Adapun manfaat dari penelitian ini, yaitu sebagai sumbangan pengetahuan tentang pemanfaatan media digital dikaitkan dengan literasi masyarakat. Secara praktis penelitian ini dapat menjadi salah satu pilihan masyarakat dalam mencari informasi melalui sumber bacaan digital di tengah pandemi Covid-19.

\section{METODE PENELITIAN}

Metode penelitian yang digunakan adalah kajian literatur berdasarkan pada eksplorasi literatur dari hasil kajian-kajian terdahulu. Literatur-literatur tersebut berupa buku, hasil survey, media online, dan artikel penelitian nasional hingga internasional (Satria, 2020). Sumber-sumber literatur yang dimanfaatkan sebagai dasar bagi kajian ini telah ditetapkan relevansinya dengan pokok penelitian. Pendekatan penelitian yang digunakan dalam kajian artikel ini ialah melalui penelitian kualitatif studi literatur-fenomenologi, seputar perilaku masyarakat dalam memanfaatkan teknologi digital sebagai bahan literasi di tengah Pandemi Covid-19. Analisis yang digunakan adalah studi mendalam atas domain dan subdomain dari pokok kajian, dan didukung oleh sintesis setiap gagasan berdasarkan literatur maupun sumber dari media daring yang menjadi rujukan pustaka yang digunakan oleh peneliti.

Penelitian ini dilaksanakan melalui hasil identifikasi permasalahan berkaitan dengan perilaku masyarakat dalam memanfaatkan teknologi digital sebagai bahan literasi di masa Pandemi Covid-19. Adapun instrumen yang digunakan ialah observasi, dan studi dokumentasi. Untuk menganalisis data yang telah diperoleh, digunakan reduksi data, display data serta penarikan kesimpulan (conclution).

\section{HASIL DAN PEMBAHASAN}

\section{HASIL PENELITIAN}

\section{Perilaku Masyarakat di Masa Pandemi Covid-19}

Pandemi Covid-19 membuat sebagian besar masyarakat Indonesia harus belajar dan bekerja dari rumah. Meskipun masih ada juga yang masih harus berkegiatan di luar rumah. Masyarakat yang mematuhi himbauan pemerintah tentu akan tetap berdiam diri di rumah.

Penelitian yang dilakukan (Bayu et al., 2020) mengatakan bahwa pada masa pandemi, akses internet dan media sosial memiliki potensi untuk membantu masyarakat umum dalam memodifikasi perilaku untuk meningkatkan kesehatan fisik, mental, dan perilaku. Secara khusus, intervensi media sosial memiliki beberapa keuntungan, termasuk aksesibilitas yang luas melintasi hambatan geografis yang bisa menjangkau batasan spasial dan efisiensi biaya. Saat ini, pertumbuhan situs jejaring sosial membawa peluang baru untuk menyebarluaskan intervensi kesehatan masyarakat dan mempromosikan peningkatan besar di bidang perilaku kesehatan. 
Dai (2020), mengatakan bahwa sikap dan perilaku masyarakat saat ini tergantung pada informasi yang didapat. Oleh sebab itu, memilih dan memilah informasi yang diterima sangat penting dilakukan. Karena penerimaan informasi ini juga berkaitan erat dengan imunitas seseorang. Selain itu, adanya stigma sosial ini menyebabkan masyarakat yang mengalami gejala atau bahkan dinyatakan positif Covid-19, memilih untuk menyembunyikan hal tersebut karena melihat adanya diskriminasi yang diterima. Padahal, hal ini justru berbahaya karena mampu mempercepat penularan.

Penelitian (Widodo, 2020), mengungkapkan bahwa WhatsApp menjadi pilihan utama responden dalam mengakses informasi Covid-19. Sebanyak 42,90\% responden mengaku lebih sering menggunakan Whats $A p p$ dari pada media sosial lainnya. Pada peringkat kedua media sosial yang sering digunakan adalah instagram dengan jumlah 23,20\%. Peringkat ketiga adalah facebook dengan jumlah pengguna 19,60\%. Media sosial lainnya seperti Twitter, Youtube, dan lain-lain jika diakumulasi digunakan oleh responden sebanyak $14,30 \%$. Data di atas menunjukkan bahwa penyebaran informasi terkait dengan Covid-19 lebih banyak menggunakan WhatsApp dari pada media sosial lainnya.

Media massa memiliki peran penting dalam mengurangi stigma sosial yang ada. Berdasarkan artikel (Insan Bumi Mandiri yang diakses melalui internet, 2020), kebiasaan masyarakat di tengah pandemi Covid-19 yang paling banyak masyarakat lakukan adalah memantau berita untuk mendapatkan informasi terkini terkait penyebaran Covid-19, pemantauan berita masyarakat dapatkan dari berbagai sumber informasi digital. Selanjutnya, kebiasaan lain masyarakat adalah membeli makanan berbasis online, kebiasaan masyarakat selanjutnya adalah menonton drama korea melalui live streaming atau sistem download sebagai upaya penghilang stress. Dan yang terakhir adalah masyarakat semakin aktif dalam berbelanja online di masa pandemi.

Berdasarkan artikel di atas, (Insan Bumi Mandiri yang diakses melalui internet, 2020) setelah melewati masa-masa PSBB, kebiasaan masyarakat di tengah pandemi selanjutnya, ialah masyarakat banyak sekali yang memulai berkebun dan bercocok tanam di sekitar rumahnya, masyarakat juga rajin melakukan aktivitas olahraga di dalam rumah demi menjaga kesehatannya, dan masyarakat banyak yang mengisi hari-harinya di tengah pandemi ini dengan merenovasi rumah

Menurut penelitian (Muslih, 2020) pada masa pandemi Covid-19 ini, banyak menimbulkan rasa kemanusiaan, empati, dan rasa kebersamaan yang sangat tinggi di masyarakat serta timbul rasa ingin saling membantu orang lain yang terkena dampak pandemic (Wulandari, 2020) sehingga masyarakat lainnya juga semakin gemar berdonasi online.

\section{Fungsi Media Digital dalam Kegiatan Pembelajaran Belajar dari Rumah di masa pandemi Covid-19}

Semenjak Covid-19 mulai menyebar luas, kebiasaan proses belajar berubah menjadi sistem online dengan menggunakan ponsel, tablet, laptop, ataupun komputer masingmasing pelajar. Perubahan kebiasaan belajar ini untuk mengantisipasi adanya kontak fisik secara langsung yang dapat memberikan pengaruh besar terhadap penyebaran Covid-19. Penggunaan media digital merupakan suatu kebiasaan baru bagi masyarakat dalam beraktivitas, khususnya dalam melaksanakan proses pembelajaran. Gadget dan media digital menjadi peralatan utama yang harus digunakan dalam proses Pembelajaran Jarak Jauh (PJJ).

Menurut Siregar dkk dalam bukunya (Santoso \& Santosa, 2020), mengatakan bahwa 
teknologi yang digunakan dengan basis internet dan teknologi multimedia dalam pembelajaran dapat menjadi alternatif dari pelaksanaan dalam kelas/ruangan yang sering dilakukan. Di antara media pembelajaran daring yang banyak digunakan adalah layanan google classroom. Google classroom adalah salah satu produk dari google. Google classroom merupakan serambi pembelajaran blended yang dirancang untuk memudahkan dunia para pendidik dalam merancang, membagikan, dan mengelompokkan materi, penugasan/ instruksi, angket tanpa kertas (paperless).

Dilansir dari Website Kata Data (2020) menunjukkan bahwa penggunaan WhatsApp di kelas telah meningkatkan motivasi siswa pendidikan tinggi. Teknik WhatsApp diakui dapat menghasilkan efek signifikan pada keterampilan siswa pendidikan tinggi, dan ternyata penggunaan mediasi WhatsApp terbukti efektif. Persepsi peserta tentang penggunaan WhatsApp dalam pembelajaran menunjukkan bahwa umumnya peserta memiliki sikap positif.

Selanjutnya laman "Rumah Belajar" juga marak diakses siswa-siswi sebagai media pembelajaran di tengah pandemi. Aplikasi "Ruang Guru" pun menjadi primadona sebagai aplikasi yang terlibat dalam proses pembelajaran selama pandemi. Aplikasi Edmodo lebih sering digunakan pendidik untuk memberikan informasi pembelajaran karena dirasa lebih mudah diakses oleh siswa dan siswinya.

Selain aplikasi pembelajaran, penggunakan media sosial di bulan April 2020 lebih aktif diakses oleh masyarakat. Facebook menjadi media sosial yang paling banyak diakses oleh masyarakat ketika pandemi. Selanjutnya, Youtube juga menjadi media sosial kedua yang paling disenangi masyarakat. Kemudian, Whats $A p p$ juga mejadi media sosial yang digunakan paling aktif dibanding media sosial chating lainnya.

\section{PEMBAHASAN}

\section{Perilaku Masyarakat di Masa Pandemi Covid-19}

Hari ini kita telah sampai di mana masa perkembangan teknologi mulai masuk dalam kehidupan masyarakat. Berdasarkan hasil penelitian di atas, perilaku masyarakat di masa pandemi Covid-19, masyarakat semakin dekat dengan media digital sebagai alat yang dapat dimanfaatkan untuk mendapatkan informasi apapun. Masyarakat semakin gemar membaca informasi pada media digital. Penelitian (Purandina \& Winaya, 2020), mengatakan bahwa masyarakat digital harus melek dengan literasi digital. Literasi digital, merupakan sebuah kecakapan atau pengetahuan tentang penggunaan media digital, alat-alat komunikasi, atau jaringan dalam menemukan, mengevaluasi, menggunakan, membuat informasi, dan memanfaatkannya secara sehat, bijak, cerdas, cermat, tepat, dan patuh hukum dalam rangka membina komunikasi dan interaksi dalam kehidupan sehari-hari (Furman, 2015).

Sementara Taylor (2019) dalam bukunya "The Pandemic of Psychology", menjelaskan bagaimana pandemi penyakit mempengaruhi psikologis orang secara luas dan masif, mulai dari cara berpikir memahami informasi tentang sehat dan sakit, perubahan emosi (takut, khawatir, cemas), dan perilaku sosial (menghindar, stigmasisasi, perilaku sehat) (Agung, 2020).

Kesalahan terbesar masyarakat dalam memantau informasi terkait pandemi Covid-19 adalah dengan mudahnya menelan informasi. Agung (2020) mengatakan media sosial twitter dan instagram, telah membantu dalam mengarahkan masyarakat ketika mengetik kata kunci "Covid-19" dalam kolom pencarian. Namun, pemahaman akan informasi dari media digital dan media sosial tidak dicerna dengan baik, sehingga banyak masyarakat yang memiliki kehilangan motivasi hidup dan memiliki rasa takut berlebihan. 
Penelitian(Bayu etal., 2020), mengungkapakan bahwa penyebaran informasi terkait Covid-19, media sosial atau bentuk teknologi lainnya dari bentuk pendidikan, yang sebagai institusi sosial perkembangannya turut dipengaruhi oleh pertumbuhan media yang cepat. Media selalu menjadi lembaga social, banyak persepsi dan norma dalam masyarakat didasarkan pada informasi yang mereka terima terlebih lagi informasi terkait Covid-19. Sebelum mengarah pada media sosial, media cetak dapat dijadikan sebagai sebuah contoh.

Penelitian Agung (2020) mengungkapkan terdapat perubahan perilaku masyarakat yang diakibatkan oleh pandemi Covid-19. Perubahan itu berasal dari inisiatif sendiri maupun himbauan atau perintah dari otoritas yang berwenang. Misalnya, jaga jarak sosial ketika berinteraksi, dan peningkatan solidaritas masyarakat dalam bentuk kepedulian dan perilaku prososial pada masa pandemi. Di sisi lain, pandemi dapat meyebabkan perubahan perilaku yang berdampak gejolak sosial di tengah masyarakat.

Muslih (2020) memaparkan bahwa kebiasaan individu dalam berkomunikasi dan berinteraksi satu sama lain dengan bertemu fisik tidak lagi menjadi prioritas ketika terjadinya wabah atau pandemi saat ini. Komunikasi dan interaksi segera akan digantikan dengan cara bertemu dalam dunia maya atau disebut virtual. Transformasi metode berkomunikasi tersebut menjadi sebuah tantangan tersendiri untuk seluruh lapisan masyarakat di dunia. Kegiatan pendidikan yang biasanya dilakukan di lingkungan gedung sekolah bisa tergantikan dengan modus belajar online (Khasanah et al., 2020), pekerjaan nonteknis yang biasanya dilakukan di kantor-kantor bisa diganti dengan bekerja dari rumah masing-masing individu secara daring (online), kegiatan berdagang yang biasanya di toko-toko fisik/offline bisa tergantikan dengan aplikasi market place virtual, berbagai pertemuan bisa digantikan dengan aplikasi semisal zoom, whatsapp, google meet dan lain-lain, serta kegiatan pementasan pun dilakukan melalui aplikasi Youtube dan sebagainya.

Menjaga kesehatan badan merupakan salah satu prioritas tertinggi selama masa pandemi. Banyak masyarakat yang enggan beranjak dari tempat tidurnya ketika pandemi dimulai, namun kesadaran masyarakat semakin tumbuh dengan adanya berbagai informasi yang dibaca dari berbagai sumber bahwa pentingnya menjaga kesehatan di tengah pandemi Covid-19.

Kesempatan menghabiskan waktu bersama keluarga merupakan sebuah anugerah di tengah pandemi ini, Dalam masa new normal, sebagian masyarakat mungkin akan tetap berada di rumah. Banyak masyarakat yang mengambil kesempatan untuk mendapatkan suasana baru di rumah dengan harga yang lebih terjangkau dan membuat rumah lebih nyaman, baik untuk belajar, maupun bekerja. Hal tersebut dilakukan dengan alasan agar rumah menjadi tempat yang paling nyaman dalam melakukan aktivitas bekerja dan belajar di dalam rumah.

Masyarakat lain yang tidak memiliki kesempatan berdiam di rumah adalah para tenaga medis yang berjuang melawan pandemi Covid-19. Platform-platform untuk berdonasi pun banyak bermunculan dengan tujuan membantu pejuang keluarga yang ekonominya terdampak karena Covid-19, pengadaan Alat Pelindung Diri (APD) untuk tenaga medis di garda terdepan, dan lain sebagainya. Donasi online memudahkan masyarakat untuk berkontribusi untuk kemanusiaan.

Secara umum bila melihat pada faktafakta di atas, Purandina \& Winaya (2020) mengungkapkan bahwa kemampuan literasi digital ini harus dimiliki oleh setiap individu yang berinteraksi di dunia digital. Jika tidak, 
hal ini dapat mengancam pengguna media digital tersebut, misalnya, akan mudahnya memprovokasi atau diprovokasi, termakan hoax, menipu atau ditipu, hacking atau pencurian data, dan lain-lain (Fitriarti, 2019).

\section{Fungsi Media Digital dalam Kegiatan Pembelajaran "Belajar dari Rumah" di masa pandemi Covid-19}

Penelitian Purandina \& Winaya (2020), mengungkapkan bahwa selama pandemi COVID-19 terjadi peningkatan penggunaan aplikasi digital (Mashabi, 2020). Walaupun, memang peningkatan ini terjadi jauh dari sebelum adanya pandemi ini. Setelah diamati lebih jauh, pandemi ini cukup mempengaruhi, hampir semua orang sekarang ini bergantung kepada dunia digital atau dunia maya (digital world).

Peningkatan pemanfaatan aplikasi digital ini memiliki tujuan tertentu, misalnya media sosial, game, harian/koran digital, e-learning, dan aplikasi pelayanan seperti gojek dll. Memang tidak bisa disamakan aplikasi apa yang sering digunakan oleh setiap generasi namun yang pasti pergerakan atau kehidupan di dunia sekarang ini sudah hampir seimbang dengan dunia nyata (Purandina \& Winaya, 2020).

Proses pembelajaran pada masa pandemi Covid-19 dilakukan melalui media digital dan beberapa aplikasi yang mampu menunjang proses pembelajaran. Hal ini menjadi sesuatu yang dapat memberikan peluang positif dan negatif bagi perkembangan literasi masyarakat khususnya orang tua yang mengasuh anak usia sekolah.

Dari beberapa kajian yang ditelaah, sudah banyak sekali yang mengkaji mengenai literasi digital. Literasi digital sama pentingnya dengan membaca, menulis, berhitung, dan disiplin ilmu lainnya. Masyarakat hendaknya dapat bertanggung jawab terhadap penggunaan teknologi sebagai wahana atau alat dalam proses pembelajaran dan media untuk berinteraksi dengan lingkungan sekitarnya. Teknologi digital memungkinkan orang untuk berinteraksi dan berkomunikasi.

Latip (2020) mengatakan bahwa di masa pandemi ini pembelajaran dapat terlaksana dengan menggunakan berbagai platform, baik berupa learning management system maupun bentuk video conference. Learning management system yang banyak digunakan diantaranya, google classroom dan porta-portal E-learning yang dimiliki oleh Sekolah atau Perguruan tinggi. Sementara itu, aplikasi video conference yang banyak digunakan selama pembelajaran jarak jauh diantaranya, aplikasi zoom, google meet, dan visco webex. Selain aplikasi-aplikasi tersebut, Whatsapp Group pun menjadi alternatif dalam pelaksanaan pembelajaran jarak jauh. Namun demikian, tidak sedikit pengajar dan pembelajar yang kesulitan menggunakan aplikasi-aplikasi tersebut dikarenakan keterbatasan sarana penunjang pembelajaran jarak jauh, khususunya dukungan teknologi dan jaringan internet. Selain itu Kemdikbud pun membuat program belajar pada saluran TVRI dengan harapan bisa diakses oleh semua kalangan di seluruh penjuru Indonesia.

Kesiapan sumber daya manusia merupakan bagian penting dalam keberhasilan pelaksanaan pembelajaran jarak jauh, kesiapan ini berkaitan dengan kemampuan pengajar dan pembelajar dalam menggunakan serta mengelola segala sistem teknologi yang digunakan dalam proses pembelajaran jarak jauh. Kemampuan penggunaan dan pengelolaan sistem teknologi, informasi dan komunikasi ini sering disebut literasi teknologi, Literasi teknologi menjadi faktor penting dalam pembelajaran jarak jauh selama masa pandemi Covid-19. Kompetensi dan literasi dalam menggunakan komputer dan berselancar di dunia maya menjadi keterampilan dasar yang diperlukan dalam pelaksanaan PJJ (Latip, 2020). 
Berdasarkan hasil penelitian, penggunaan aplikasi dalam media digital menjadi sebuah trend masyarakat yang dapat membantu proses pencarian informasi dan media pembelajaran. Namun, di sisi lain proses pembelajaran melalui aplikasi media digital seharusnya meningkatkan control orang tua terhadap anaknya ketika ia belajar di rumah. Kemudian, orang tua harus memberikan bahan bacaan untuk anak dan keluarga, dengan menyediakan bahan bacaan yang benar dan dapat dipertanggungjawabkan kebenarannya.

Tujuan dari penguatan budaya literasi digital di keluarga terutama bagi anak-anak adalah untuk meningkatkan kemampuan berpikir kritis, kreatif, dan positif dalam menggunakan media digital dalam proses pembelajaran juga kehidupan sehari-harinya. Orang tua juga diharapkan mampu secara bijak dan tepat mengarahkan dan mengembangkan budaya literasi digital di keluarga. Selain itu, penguatan budaya literasi di keluarga juga meningkatkan kemampuan anggota keluarga dalam menggunakan dan mengelola media digital secara bijak, dan cermat, juga tepat untuk membina komunikasi dan interaksi antaranggota keluarga dengan lebih harmonis serta untuk mendapatkan informasi yang bermanfaat bagi kebutuhan keluarga.

Adapun bentuk-bentuk sasaran literasi digital dalam keluarga yaitu sebagai berikut: 1) Meningkatkan jumlah dan variasi bahan bacaan literasi digital di rumah;2) Memotivasi anggota keluarga untuk membaca bahan bacaan literasi digital; 4) Memantau akses anggota keluarga terhadap penggunaan internet secara bijak; 5) Memanfaatkan media digital secara positif dalam berbagai kegiatan di keluarga.

\section{PENUTUP}

Pandemi Covid-19 memberikan perubahan besar terhadap perilaku masyarakat dalam beberapa aspek. Perubahan itu berasal dari inisiatif sendiri maupun imbauan dari otoritas yang berwenang. Misalnya, jaga jarak sosial ketika berinteraksi, dan tetap di berada di dalam rumah. Selain itu, perubahan perilaku inisiatif masyarakat itu sendiri adalah beberapa kegiatan positif yang dilakukan di dalam rumah, serta terjadinya peningkatan solidaritas masyarakat dalam bentuk kepedulian dan perilaku prososial pada masa pandemi.

Pemanfaatan media digital pada proses pembelajaran jarak jauh atau proses pembelajaran "Belajar dari Rumah" sangat diperlukan keluarga. Keluarga menjadi tolak ukur keberhasilan meningkatkan literasi digital untuk anggota keluarganya dengan memanfaatkan akses internet melalui media digital secara bijak. Kesiapan sumber daya manusia merupakan bagian penting dalam keberhasilan pelaksanaan pembelajaran jarak jauh, kesiapan ini berkaitan dengan kemampuan pengajar dan pembelajar dalam menggunakan serta mengelola segala sistem teknologi yang digunakan dalam proses pembelajaran dari rumah. Selain itu, keluarga memiliki tanggung jawab memotivasi anggota keluarga untuk menggali bahan bacaan secara digital dan tidak terjebak dalam penyebaran informasi yang tidak benar.

Dapat disimpulkan bahwa media selalu menjadi lembaga sosial. Ketika teknologi mulai tumbuh ke dalam setiap aspek kehidupan manusia, maka media adalah sumber utama informasi dan kebutuhan yang terus meningkat untuk kehidupan. 


\section{DAFTAR PUSTAKA}

\section{Internet, Buku Online, Buku, Artikel:}

Agung, I. M. (2020). Memahami Pandemi COVID-19 dalam Perspektif Psikologi Sosial. Psikobuletin: Buletin IImiah Psikologi, 1(2), 68-84.

Bayu, M., Sampurno, T., Mada, U. G., Kusumandyoko, T., Surabaya, U. N., Islam, M. A., Surabaya, U. N., \& Branding, V. (2020). Budaya Media Sosial , Edukasi Masyarakat, dan Pandemi COVID-19. SALAM Jurnal Sosial Dan Budaya Syar I, June. https://doi.org/10.15408/sjsbs. v7i5.15210

Bungai, J., Perdana, I., \& Affandi, M. (2020). Implementasi literasi digital melalui pengembangan website desa sebagai upaya pemberdayaan masyarakat. Jurnal AKRAB!, XI(1), 54-63.

Dai, N. F. (2020). Stigma Masyarakat Terhadap Pandemi Covid-19. Seminar Nasional Problematika Sosial Pandemi Covid-19, 66-73. Gilster, P. Digital literacy. New York: Wiley,1997.

https://www.kemdikbud.go.id/main/blog/2020/05/ kemendikbud-terbitkan-pedomanpenyelenggaraan-belajar-dari-rumah

Imran, Hasyim Ali (2010). Literasi Teknologi Informasi dan Komunikasi Masyarakat Pedesaan. Jurnal Studi Komunikasi dan Media, Juli 2010

Insan Bumi Mandiri. (Mei 2020). 8 Perilaku yang Berubah Selama Virus Covid. Diakses dari https://insanbumimandiri.org/id/post/8perilaku-yang-berubah-selama-viruscovid. 20 September 2020.

Latip, A. (2020). KOMUNIKASI PADA PEMBELAJARAN JARAK JAUH DI MASA PANDEMI COVID-19. Jurnal Edukasi Dan TEknologi Pembelajaran, 1(June), 107-115. https://doi.org/10.37859/ eduteach.v1i2.1956

Muslih, B. (2020). Urgensi Komunikasi dalam Menumbuhkan Motivasi di Era. Jurnal Penelitian Manajemen Terapan (PENATARAN), 5(1), 57-65.

Nurohmah, R., Aini, N., Kholik, A., \& Maryani, N. (2020). Literasi Media Digital Keluarga di Tengah Pandemi COVID-19 dilakukan seperti biasanya. Rutinitas orang tua yang bijak dalam mengambil anak dengan cinta bukan dengan cara. Jurnal Pengabdian Pada Masyarakat Educivilla, 1(2). https://doi. org/10.30997/ejpm.v1i2.2834

Peraturan Menteri Kesehatan Nomor 9 Tahun

Peraturan Pemerintah Nomor 21 Tahun 2020

Purandina, I. P. Y., \& Winaya, I. M. A. (2020). Berkarakter dalam Literasi Digital : Menjaga Kedamaian Umat di Era Digital. Beragama Dalam Damai, 1-18.

Ratriani, VR. (Juni 2020). Pandemi Covid-19, Berikut 5 Perubahaan Kebiasaan Masyarakat. Diakses dari

ht t p s:// w w w. kompas.com/tren / $\mathrm{read} / 2020 / 05 / 06 / 130300865 /$ pandemiCovid-19-berikut-5-perubahaankebiasaan-masyarakat?page=all. Pada tanggal 20 September 2020.

Sagala, S. (2013). Konsep dan Makna Pembelajaran. Bandung: Alvabeta

Santoso, D. H., \& Santosa, A. (2020). Covid-19 dalam ragam Tinjauan Perspektif (D. H. Santoso \& A. Santosa (eds.); Cetakan Pe). MBridge Press.

Satria, A. (2020). Sosietas Jurnal Pendidikan Sosiologi Kearifan Lokal dalam Menghadapi Pandemi Covid-19: Sebuah Kajian Literatur. 10(1), 745-753.

Surat Edaran Mendikbud Nomor 4 Tahun 2020

Surat Edaran Menpan RB Nomor 19 Tahun 2020

Sutrisna, I. P. G. (2020). Gerakan literasi digital pada masa pandemi covid-19. 8(2), 268-283. https://doi.org/10.5281/zenodo.3884420

Undang-undang Bencana Nomor 24/2007

Widodo, A. (2020). Teror Informasi dan Perilaku Mahasiswa Dalam Penggunaan Media Sosial Selama Pandemi Covid-19. Jurnal Ilmu Pendidikan PKn Dan Sosial Budaya, 4(1), 45-58. 